\title{
The Next Trend in Design
}

by James Woudhuysen

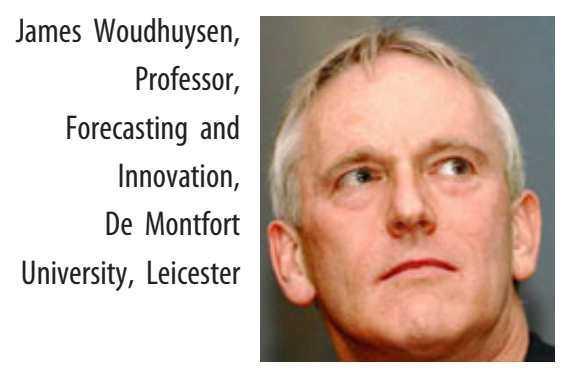

n April 2011, Bruce Nussbaum, one of the foremost advocates of design

thinking (DT), pronounced it a "failed experiment" (Nussbaum, 2011).

After this summary verdict, Nussbaum asked, naturally enough, "What's next?" This article replies to that question.

Nussbaum's own reply was interesting. He upheld what he called "humanistic design," and described it as "a huge advance in the field." However, he did not define, still less give examples of, humanistic design. Instead, he went on to outline a third concept- "creative intelligence." Around that concept, he plans to publish a book in late 2012.

For designers and design managers, having an opinion about trends in design has always been important. In prewar America alone, industrial designers such as Henry Dreyfuss, Walter Dorwin Teague, Raymond Loewy, and Norman Bel Geddes positioned themselves as knowing a thing or two about the future. Fashion design, too, has long been oriented to color forecasting, and trend forecasting in general. Design managers have often pronounced one trend dead and upheld another one. Still, it is a bit new to do both of these things, and then say that a third designerly world view deserves a book.

A cursory inspection of trends in the handling of design trends, then, reveals a certain relativism of outlook. Anything goes, pretty much: One projection may be as good as another, and much depends on this or that design manager's point of view. In other words, design managers both adopt and abandon intellectual trends rather quickly nowadays. Before we suggest what the next trend in design should be, therefore, we should first ask: Just why are trends so trendy these days?

Of course, when designers such as Loewy or Bel Geddes pushed through ideas about the future to clients, there was always an element of arbitrariness about their views. In their time, style was of unrivaled importance. The subjective approach of great designers had yet to give way to more organized conceptions of design management, or of the future. However, for all the realities of today's global production, both design managers and celebrity designers still lack a sensible compass to steer them toward The Next Big Thing in Design.

Perhaps, really, two trends in the handling of design trends are at issue here. On the one hand, and certainly over the past 15 years or so, the growing 
impulse for companies, design managers, and designers has been to cast the future in terms of design for corporate social responsibility, ethics, lowering adverse impacts on the environment, and-above all-lowering emissions of $\mathrm{CO}_{2}$.

When designers put forward a broadly Greenish interpretation of the future, as a future of sustainability, they suggest a trend of planetary significance. This story of the future is more imposing than other grand narratives in design, such as Modernism, Postmodernism, or an orientation to users.

The scale of the trend predicted here-The Future is Green-looks large. Also, advocates of this point of view feel that, when they uphold an acceleration of that trend, they are design activists who are morally right and who will have history on their side. However, the relentless and repetitive subordination of all goals and most other anticipated trends to the demand for sustainable design suggests that something is wrong. Steering professionals to the Next Trend in Design has been done with a compass that is stuck. Here the future is always just an extension of the present. The trend is: Redouble efforts to save the earth-against which all other trends, whether objective or hoped for, are of little moment.

On the other hand, the willingness of the design world to proclaim and then drop overfamiliar and ill-thought-out lists of many new trends is today very high. Here the compass spins around. Often described as "futures," and emboldened by the multiple options of scenario planning, the future here is variable, protean, and hard to pin down. Interestingly, too, the spread of multiple, pluralistic conceptions of the future is expressed in the activist form of manifestos for design (though not for design management). Since 1883 , more than 60 design manifestos have been published; and, confirming the "depends on your point of view" mentality, the trend is for more manifestos to be published each year. No fewer than 35 have come out since 2000 (Emerson, 2009).

The desire to mold the world is commendable, but most designers and design managers lack training in the analysis of trends, and that doesn't help. Worse, design managers in particular have a weakness for taking on new management doctrines in an eclectic and far-too-cozy spirit. Particularly in the United States, where Tom Peters' and Robert Waterman Jr.'s In Search of Excellence (1982) popularized trendy catchphrases for corporations, design managers have drawn upon bestselling management books as an inspiration for thinking about the next trend in design.

In 1986, just a few years after Peters and Waterman published their book, BusinessWeek ran a cover story on business fads (see Figure 1; Byrne, 1986). The cover alone shows how capricious thinking about trends can be-with business managers as well as design managers.

At least Business Week had tongue firmly in cheek. Yet given the alacrity with which design managers uphold and then forget about future trends, it's worth asking: Where do such trends really come from? How can we forecast the next one, and be sure that it won't simply be a transient fad? Most important: How can we make a simple, convincing, intelligent, and un-faddish new argument for design, which absorbs those merits that DT has, but which moves designers on toward a more practical and yet more ambitious practice?

\section{How to know when marginal trends move into the mainstream}

Influential pieces of thought leadership typically begin, in design as elsewhere, as more or less marginal musings. Two examples, one in the sphere of management and one in the sphere of economics, suggest how marginal intellectual trends come to gain popularity. That only happens when their advantages in the realm of ideas seem to be given relevance and substance by new developments in the real world.

\section{"Stakeholders"}

While he was George Bush's deputy secretary of state, in 2005, current World Bank president Robert 


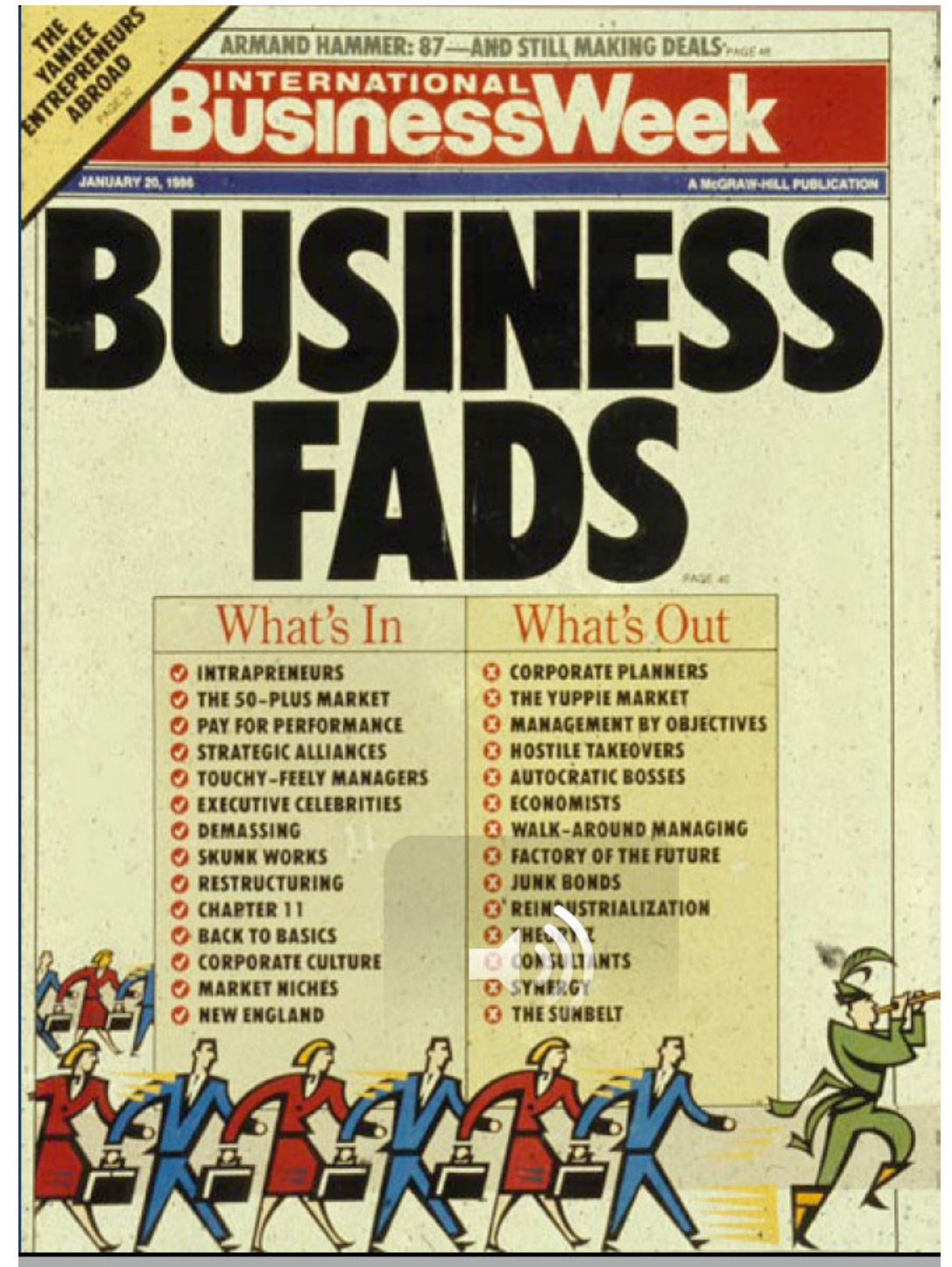

Figure 1. Where were you in 1986 ? It's notable that "touchy-feely managers" are still very much "in" today...

Zoellick gave a speech on China. He called on that country to go further than basic diplomacy in international affairs and instead become a responsible stakebolder, capable of working with the United States "to sustain the international system" (Zoellick, 2005). Here, ironically enough, the "stakes" alone suggest the force that the idea of "stakeholder" has acquired. It is used in the management not only of corporations, but also of international affairs.

It is used in design management too. One of the unwritten rules in DT is that managers of design projects should, for greater clarity, seek the participation and support of stakeholders. Now, our interest here is not to question the concept of different groups having a stake in a design project-even if this does tend to imply a rather harmonious account of power and influence in the corporation. Nor can we go into the privileged place that DT accords to users when compared with other alleged stakeholders, such as suppliers, retailers, and employees in research and development (R\&D), or employees in marketing.

No-our interest in stakeholders lies around the intellectual history of the idea and, particularly, how it gained mass recognition only when the moment was ripe for it.

Now at the University of Virginia, R. Edward Freeman is one of the pioneers of what is now known as "stakeholder theory." As he wrote in the California Management Review in 1983, the original idea emerged in a somewhat obscure way:

The stakeholder notion is indeed a deceptively simple one. It says that there are other groups to whom the corporation is responsible in addition to stockholders: those groups who bave a stake in the actions of the corporation. The word stakebolder, coined in an internal memorandum at the Stanford Research Institute in 1963, refers to "those groups without whose support the 
organization would cease to exist." The list of stakeholders originally included shareowners, employees, customers, suppliers, lenders, and society. (Freeman and Reed, 1983, p. 89)

At its inception in 1963, therefore, "stakeholder" appeared only in a memo at the Stanford Research Institute's offices in Menlo Park, California.

So the idea has been around a long time. How can we trace its current force? As Freeman and Reed note, the stakeholder concept developed only slowly during the late 1960s and early 1970s. However, in1977 the Wharton School of Business began to research the concept. By the late 1970s, Freeman writes, strategic management processes had to consider "nontraditional business problems" in terms of "government, special interest groups, trade associations, foreign competitors, dissident shareholders, and complex issues such as employee rights, equal opportunity, environmental pollution, consumer rights, tariffs, government regulation, and reindustrialization" (Freeman and Reed, 1983, p. 90). Here, in implicitly referring to the corporate and social priorities, and the tone, of the era of President Jimmy Carter, Freeman and Reed do a good job of suggesting how the concept of stakeholders moved from memo to the world of "management science."
Pressures from the world of objective circumstance gave some legs to what had previously been little more than just a subjective idea. The idea of stakeholders, however, was still confined to academia. Despite Freeman following up his 1983 article with a book that became the bible of stakeholder theory (Freeman, 1984), the Reagan years proved inhospitable to stakeholders. The idea had to wait for the "I feel your pain" sensitivities of President Bill Clinton (1993-2001) and Prime Minister Tony Blair (1997-2007).

A key year for the mainstreaming of "stakeholder" came in 1995. In Europe, the environmentalist lobby group Greenpeace managed to embarrass Shell into dropping its plans to dispose of its Brent Spar oil buoy in the North Sea. The episode vividly confirmed how firms need to think about constituencies beyond their shareholders, their managers, and their direct customers. In Britain, in the same year, leading British economist Will Hutton devoted a whole chapter of his bestselling book The State We're In to "stakeholder capitalism." Hutton called for the participation of responsible trade unions in regulating capitalism, and praised Europe as a patron of environmental standards and rules of governance, thus making it "the stakeholder company" (Hutton, 1995, p. xxii).

In America, it was again in 1995 that we find Bill Clinton referring to stakeholders, and signif- icantly he does so around two key issues: science and technology, and the environment. In a March 29th message to Congress on science and technology, Clinton warmly refers to "the forums and workshops that have drawn in thousands of experts and stakeholders to help develop priorities in areas as diverse as fundamental science; environmental technology; and health; safety; and food research" (Clinton, 1995a).

Within a week, Clinton was talking stakeholders to Congress again. Referring to the Environmental Protection Agency, a regulatory body, he said, "EPA is embarking on a new strategy to make environmental and health regulation work better and cost less. This new common sense approach has the potential to revolutionize the way we write environmental regulations. First, EPA will not seek to adopt environmental standards in a vacuum. Instead, all the affected stakeholders-representatives of industry, labor, State governments, and the environmental community - will be involved from the beginning" (Clinton, 1995b).

After 1995, the stakeholder perspective became integrated into U.S. government thinking. A search for "stakeholder" through the online archive of the American Presidency Project's excellent record of public papers offers some suggestive results (see Table 1).

Not too much reliance need be put on these numbers. Nevertheless, 


\begin{tabular}{l}
\begin{tabular}{|l|l|l|l|l|l|l|l|l|l|l|l|l|l|l|l|l|l|}
\hline \multicolumn{1}{|l|}{ Number of mentions } \\
\hline 1 & 4 & 1 & 4 & 7 & 7 & 12 & 3 & 3 & 2 & 3 & 2 & 8 & 7 & 7 & 1 & 24 & 35 \\
\hline Year \\
\hline 94 & 95 & 96 & 97 & 98 & 99 & 00 & 01 & 02 & 03 & 04 & 05 & 06 & 07 & 08 & 09 & 09 & 10 \\
\hline President
\end{tabular} \\
\hline
\end{tabular}

Table 1. Number of mentions of the word "stakeholder" in the public papers of U.S. presidents, 1994-2010.

the broad upward trend is clear enough. Even with George W. Bush, a Republican, use of "stakeholder" grew toward the end of his term; and with Barack Obama, it has gone into overdrive.

The first lesson of this brief intellectual history is simple enough. To predict the next trend in design, design managers need to set up an apparatus to track both mainstream and peripheral trends, bearing in mind bow changing times can give previously peripheral trends a mainstream status.

The second lesson ought to be clear too. Design managers make a mistake when they bandy about management categories like "stakeholder" without ever interrogating the category. If they want to predict the next trend in design, they need to examine the changing history and contemporary salience of categories like "stakeholder." For example, Sir Martin Sorrell, the chief of the marketing services multinational WPP, noted as early as 2002:

Well over 50 percent of what we do for our clients in advertising, media investment management, information and consultancy, public relations and public affairs, branding and identity, bealthcare and specialist communications is now directed at internal audiences. Making sure that internal audiences are onside is critically important in ensuring strategic and structural messages are transmitted to customers, clients, suppliers, investors, journalists, analysts, governments and non-governmental organizations. (Sorrell, 2002, p. 30).

Well: Is tomorrow's chief audience, or stakeholder, for communications design really an internal one?

When next they try to relate a project or program in design management to future trends, design managers would do well to think about the past and the future evolution of key categories such as "stakeholder." Even the meaning of a category such as "innovation" has changed enormously over the years. The chief thing that design managers can do to create the Next
Trend in Design is to develop a balanced but critical spirit in relation to the received categories of management, innovation, and design.

\section{Behavioral economics}

In 1970, the British artistic polymath George Melly memorably described the increasing domination of Britain by pop culture as a "revolt into style" (Melly, 1970). We can again, but more briefly, explore the interplay between ideas and circumstance by looking into the revolt into style conducted by behavioral economics in recent years. This is a worthwhile exercise-because one thing design managers can be reasonably sure about as a trend in the future of design is that society will have a growing obsession with behavior, decision making, psychology, and the brain. ${ }^{1}$

\footnotetext{
${ }^{1}$ For a journalistic account of Paul Zak, one among many recent advocates of "neuroeconomics," see Mark Honigsbaum, "Oxytocin: Could the 'trust hormone' rebond our troubled world?" The Observer, August 21, 2011.
} 
In October 2008, Alan Greenspan, once head of the U.S. Federal Reserve Bank, testified to a packed meeting of the House of Representatives' government oversight committee. He admitted himself shocked by the "credit crunch" that had been encountered that year, and conceded that he had been partially wrong simply to leave the regulation of some financial instruments to the market. At that moment, as Duke University economics professor Dan Ariely has suggested, belief in the ultimate rationality of humans, of organizations, and of markets crumbled-definitively (Ariely, 2009).

The inroads made by behavioral economics on the conventional sort, however, began well before Greenspan's mea culpa, and at the strangest of places: the conservative RAND Corporation, a Cold War forecasting house based in Santa Monica, California. There, in 1961, Daniel Ellsberg began his later career as an insider dissenter in Washington by flouting some standard axioms. He proposed that, when making a decision in the face of ambiguity, a person might not take what might be the expected position - that of "maximizing a linear combination of pay-offs and probabilities" (Ellsberg, 1961).

That proposition significantly subverted the status quo in economic theory. Later in the 1960s, two Israeli psychologists, Daniel Kahneman and Amos Tversky, went farther down the path taken by Ellsberg.

By 1979, after Kahneman began a collaboration with Richard Thaler, he and Tversky outlined just how oddly people make decisions in the face of certainty, probability, losses, and gains. Partly funded-strangely enough, once more-by the Advanced Research Projects Agency of the U.S. Department of Defense, the paper used the responses of university students and staff to hypothetical choice problems. It attacked the "rational choice" axioms of economic conduct applied by Nobel economists Milton Friedman and Kenneth Arrow, describing "several classes of choice problems" in which preferences "systematically" violated those axioms (Kahneman and Tversky, 1979). The paper effectively overturned the neoclassical framework in economics, and helped win Kahneman a Nobel Prize in 2002.

The Nobel Prize meant recognition for those who had discovered the irrational side of decision making. But for this idea to be propelled into the world of mainstream economic discussion, a whole upheaval in the world economy had to occur, in the shape of the credit crunch. Only since 2008, when the U.S. economists Richard Thaler and Cass Sunstein published Nudge: Improving Decisions about Health, Wealth, and Happiness, has the idea really grown that the state's job is to act as a paternalistic "choice architect," nudging feckless and irrational consumers and taxpayers to make "informed decisions."

The special role given to irrationality in decision making had been entertained in the early 1960s, and it gained Nobel Laureate status in 2002. But the Byzantine structure and eventual collapse of Wall Street around 2008 was necessary for this previously marginal intellectual trend to become the stuff of conversation all over the West.

\section{Critiquing bestseller books on ideas can help you control the future}

To forecast the next trend in design, design managers must mobilize their critical faculties. They need to situate today's bestsellers on ideas in a careful historical context, and subject them to an equally careful critique. That way, they can synthesize their own independent view, the better to impose it, as best they can, on the future-rather than allow the future simply to impose on them.

A short summary of an argument with a bestseller on trends, Mark Penn and E. Kinney Zalesne's Microtrends: The Small Forces Behind Tomorrow's Big Changes (2007) may help. Penn, worldwide chief executive of the PR firm Burson-Marsteller, is a longtime pollster, and larger than life: He has been a key adviser to leaders as varied as Israeli prime minister Menachem Begin, Bill and Hillary 
Clinton, Bill Gates, and Tony Blair. His book sets about identifying "small, intense subgroups," complete with "needs and wants unmet." In this cause, its basic thesis is simple:

The very idea that there are a few buge trends out there, determining how America and the world work, is breaking down. There are no longer a couple of megaforces [sic] sweeping us all along. Instead, America and the world are being pulled apart by an intricate maze of choices, accumulating in "microtrends"-small, under-the-radar forces that can involve as little as 1 per cent of the population, but which are powerfully shaping our society. (Penn and Zalesne, 2007, p.xii)

For Microtrends, it was the default of just 1.7 percent of U.S. mortgages that, by precipitating the credit crunch, brought the whole U.S. economy down (Penn and Zalesne, 2007, p. xiv).

Microtrends errs because it treats the influence of marginal trends in an unmediated way. We find here a distant echo of our old friend, the butterfly in the South Atlantic that waves its wings and suddenly Affects Everything. What Microtrends neglects is a key "megaforce": society's growing fear of risk. In the years before 2008, that fear made the United States as a whole and U.S. firms prefer what economist Tyler Cowen calls "dubious financial innovations" to technological innovations (Cowen, 2011, p. 45). So it was failures in the productive parts of the U.S. economy that gave mortgages the sway they had. America's money economy stretched way beyond the means of the real economy. Leading-edge, world-beating designs and technologies, long fielded by America over a broad front, were not generally seen as a tradition worth renewing. With the exception of its triumphs in the Internet, Cowen writes, the United States was missing out on a lot of innovation.

Microtrends ignored all this. Instead, from "cougars" (older women who date younger men) and on through 81 other market niches, the bite-sized demography of Microtrends gave millions an influential capsule guide to a superficial kind of trend watching-not just in the United States and the United Kingdom, but also in Germany and Japan.

The moral of this tale for design managers is straightforward. Small trends can come to be important, but they depend on other, mediating trends for this to happen. More broadly, design managers would do well to collect and suspect more forecasts of the future and to be particularly discriminating about bestselling books on ideas.

Five principles that can assist in the future

Looking at the state of design and designers today, we can derive some five principles that can help us going forward. I say "principles" because although these are neglected in much of today's discussion on design, they were important to nineteenth-century founders of design (John Ruskin, William Morris, and others), and could do with debating today. We also like principles because, when animating particular positions on design and in design management, they represent an activist and designerly effort every bit as imposing as the efforts trumpeted by those who advocate Green design, and those who are always outlining new manifestos for design.

\section{Principle 1: Improve basic design skills}

The rise of Chinese, Korean, and Indian designers has very clear implications for their Western counterparts. The basic skills of design will increasingly become a world commodity-a bit like accountancy skills have long been part of the taken-forgranted baggage of business. As a result, designers the world over will have to be very good at differentiating their basic skills from those of other designers.

What do we mean by basic skills? At the very least, we expect the ability to

- Draw and visualize design ideas, with or without the help of IT

- Make prototypes that take account of functional, technical, and cost requirements 
- Execute design ideas with a strong eye to aesthetics

Although it downplays the significance of style, Tim Brown's account of design thinking rightly stresses the importance of visualization, and of prototypes (Brown, 2009). However, the accent above is on active, thoughtful skills of the hand. Even literacy, numeracy, and communication skills are not here, because we are talking about the more fundamental talent of designing.

In pursuit of really high standards in the manipulation of materials and media, the good design managers of the future will welcome the end of superstar designers. They will be skeptical about the more elusive claims of DT - and about the equally elusive language often used by design schools. For many years, we have had plenty of poor theory in design, design management, and design schools. The least we can demand of the Next Trend in Design is that we revive interest in the practical craft, the trade, of designing.

All around the world, and even in Asia, there is a cultural sense of drift-in the realm of design too. But designers must, to deadline, physically and/or electronically implement their ideas for those ideas to be judged, no matter in which court.

One can be tolerant of different design solutions. But make no mis- take: Tolerance, in design management as elsewhere, involves the exercise of powers of discrimination. Some design portfolios are good, but too many are not nearly good enough. The struggle for better basic skills in design means making judgments about design.

It is time that the design world revived design's basic bias to action. It is time that the design world was tougher with itself about its core competence.

\section{Principle 2: Design for lower prices}

There is no need to overdo the issue of inflation today. It is true that, in 2011, rates of price inflation were buoyant in many parts of the world. But inflation today has neither the scale nor the pervasiveness that it did in the early 1970s - the period of "stagflation," when rates of inflation were high, both West and East (see Table 2).

Despite the mixed picture on inflation today, design managers would be wise to put a special emphasis on achieving quality, but at a low cost.

Countless companies and customers across the world have been forced to tighten belts and count the pennies. When design managers propose solutions that slash lifecycle costs, clients sit up and take notice. While DT is rarely interested in cutting costs, doing just that is a great way to create

\begin{tabular}{|l|l|l|}
\hline US & 3.6 & 12.3 \\
\hline UK & 4.5 & 15.9 \\
\hline Japan & 0.2 & 23.2 \\
\hline Germany & 2.4 & about 7 \\
\hline France & 1.9 & 13.7 \\
\hline Brazil & 6.9 & about 30 \\
\hline Russia & 9.0 & not available \\
\hline India & 8.4 & 28.6 \\
\hline Indonesia & 4.6 & 40.6 \\
\hline China & 6.5 & negligible \\
\hline S Africa & 5.4 & 11.6 \\
\hline Source Organisan Economic
\end{tabular}

Source: Organisation for Economic Cooperation and Development; Wolfram Alpha.

Table 2. Rates of inflation, selected countries, July 2011 and 1975.

measurable benefits for firms and for users.

In fact, there is more to design for lower costs. As the Londonbased strategist Robert Bau has pointed out, lowering costs is a productivity strategy (Bau, 2011). To qualify as a genuine Next Trend in Design, cutting costs will mean a commitment to design ideas and practical systems that improve productivity, convenience, and the use of time.

It is the business of designers not to make more work, but to obviate more work. In this context, the idea that designers should engage with labor-intensive technologies in the pursuit of "green jobs"-making expensive, environmentally conscious goods and 
services for the middle classdeserves critical scrutiny. ${ }^{2}$

Recycling, for example, should be done through efficient, mechanized processes, not as a personal labor of penance. Similarly, employing manual laborers to "weatherize" homes is not as robust a solution as designing and building a new round of zero-emissions nuclear reactors.

Designers and design managers should take pride in making goods and services that work well, but are as cheap to buy as possible. Design managers always need to keep their feet on the ground, in the real world of customer preference; and that kind of preference very much includes a preference for low prices.

\section{Principle 3: Deepen internationalism}

While Asian designers know quite a bit about Western culture and design, Western designers know too little of the East. That has to change. Whatever the flaws of DT, its orientation to users of design, if consistently followed through, must mean a fight for greater insight into the East.

In part, the need to know more about and uphold the achievements of foreign designers stems from the exigencies of globalization. Western

\footnotetext{
${ }^{2} \mathrm{~A}$ recent survey of the U.S. experience in making green jobs, conducted by a liberal and sympathetic London think tank, concluded that "the US experience shows energy efficiency schemes have struggled to create 'green jobs,' both in quantity and quality." See Clare McNeil with Hanna Thomas, "Green Expectations: Lessons from the US Green Jobs Market," Institute for Public Policy Research, July 2011, p. 23.
}

firms such as Johnson Controls International, LEGO, and Albert Heijn are becoming adept at getting various parts of the design process handled in the East. A city such as London can play host to design studios drawn from Nokia, Nissan, Samsung, and Yamaha, while the rest of the United Kingdom hosts design teams from Black \& Decker, Herman Miller, and Tata. In Japan too, a company such as Panasonic has globalized its management of design; whereas, in the past, Panasonic's Japanese offices designed pretty much everything the company made, today Japanese teams develop just 10-20 percent of the items that Panasonic sells in emerging markets (The Economist, 2010).

Internationalism in the management of design is a realistic response to the way the world economy works nowadays. Yet it is more than that. In the quest for discrimination in design, for great basic skills and low prices, the internationalist design manager will have little time for cross-border double standards. Everyone in the world deserves the very best that design can bring.

Once more, this principle demands a critical attitude toward current developments. Take, for example, the trend toward reverse innovation, where lessons from lowcost designs aimed at emerging markets are touted as the way forward not just there, but also back in the West. Now, if famous examples set by General Electric are to be believed, there is much for the West to gain from the East here. GE's $\$ 1,000$ handheld electrocardiogram device for rural India and its $\$ 15,000$ portable, PC-based, and "software-centric" ultrasound medical imaging machines for rural China are now sold in the United States, where they are stimulating new applications for such products (Immelt et al., 2009).

This transfer of innovation from East to West is fine so long as neither the East nor the West loses sight of the need to pursue the very best technology and design solutions-everywhere in the world and, sometimes, regardless of cost. In 2003, Clayton Christensen and Michael Raynor, in their book The Innovator's Dilemma, eloquently spoke up for "good enough" ink-jet printers as an innovation that disrupted the up-market world of laser printers made by incumbent companies. Christensen and Raynor eulogized products that were cheap, simple, convenient, small, and portable, even if their performance was low. Yet if ink-jet printers have their place in the firmament of properly designed products, so do laser printers. With Asia and Africa in particular, internationalist design managers have a duty to spell out the limitations of second-best.

In the developed world, government and nongovernmental organizations, educators, media, and design commentators like to bring weak technologies to the Third World. The British government and Body Shop founders Gordon 
and Anita Roddick have backed wind-up radios. From the Schumacher Centre, near Rugby, in the West Midlands of the United Kingdom, the charity Practical Action favors hand-operated water pumps. In Miami, Florida, the One Laptop Per Child Association and in Cambridge, Massachusetts, the OLPC Foundation have since 2005 been on a "long march from radical theory to reality" to "create educational opportunities for the world's poorest children by providing each child with a rugged, low-cost, low-power, connected laptop with content and software designed for collaborative, joyful, self-empowered learning."”

No doubt the intentions behind these projects are good, but hopefully they do not herald the Next Trend in Design. Design managers must recognize that these measures are no substitute for decent national and international systems of electricity supply, irrigation, and computerization. No "Transition Town," dedicated to dealing with the challenges of climate change and peak oil, can give Africans the energy they need. ${ }^{4}$

${ }^{3}$ For more about the OLPC Foundation, see http://laptop.org/.

${ }^{4}$ The Transition Towns movement began in March 2007 when Totnes, in South Devon, England, decided to run its own currency, the Totnes pound, alongside pounds sterling. See http://totnes.transitionnetwork.org/. Transition initiatives can also be found in Granja Viana, São Paulo, Brazil, and in Mpumalanga, South Africa: see http://www.transitionnetwork.org for more information.
No amount of good design can make a mosquito net truly effective against malaria. The Next Trend in International Design cannot be condescendingly to impose dumbeddown designs on the South and the East. That would be to lower standards in those regions, and, inadvertently or not, to make their future evolution slow and narrow. For developing countries to embark on more emancipatory options will not be easy; but that's a prospect for the future much less utopian than to go on believing that "appropriate" or "intermediate" technology is the way out of their difficulties.

It is not hard to read the United Nations' Millennium Development Goals as unambitious. ${ }^{5}$ It is wrong to reflect those goals with questions for developing countries such as "How might we find lowcost alternatives to wood-burning stoves in urban slums?" or "How might we create an infant incubator that does not need an electrical supply?" If this is design thinking, it is a very shallow kind of thinking. The relevant question for developing countries is, rather: How can we explain the case for, plan, and help do the design detail of working, maintainable national systems for energy supply and

\footnotetext{
${ }^{5}$ For a critique of the UN Millennium Development Goals, see James Woudhuysen and Joe Kaplinsky, Energise! A Future for Energy Innovation (London: Beautiful Books, 2009), Chapter 7.
}

transmission that are every bit as powerful and universal as those in the West? From the holistic point of view so beloved of DT, it should be obvious that, in developing countries as elsewhere, energy infrastructure ought to be there not just to relieve the plight of poor families, but to dynamize large organizations.

\section{Principle 4: Uphold science and technology}

What the world needs now is more science and technology, not less. Every design manager should take that to heart. Where, after the 2011 nuclear accidents at Fukushima, Japan, were the clear-eyed maps integrated with charts of radiation? Where, after more than 10 years of the Human Genome Project, are the memorable graphic images of it, images that both explain and capture the popular imagination? When did designers last give Mendeleev's Periodic Table the inspired treatments it has had from the American comic singer and mathematician, Tom Lehrer (in his song "The Elements," 1959), or the Italian writer and chemist, Primo Levi (in his book The Periodic Table, 1975)?

The Next Trend in Design could be about ensuring that new recruits to corporate design functions are properly curious about science and technology. Yes, designers need to learn more history, social psychology, forecast- 
ing. But they make a mistake if they affect, in the manner of DT, to be superior to science and technology. If they are not attracted to the romance of $\mathrm{R} \& \mathrm{D}$, or to the contribution it can make, they cannot be designers or design managers fit for a new century.

Designers and design managers need to open up to corporate $R \& D$ departments. The remaining skilled experts in white coats that the West can muster deserve a fervent collaboration, not a dismissive competition. These people are not geeks, techies, nerds, or code warriors. They are subject to budget cuts, are often heroes, and must be learned from. At the same time, designers and design managers need to eschew both glib technophilia and glib technophobia. They should interrogate the boosterish market populism of Wired in IT, and of Grist in matters environmental. But they should question, too, the pessimistic advocates of a "steady state" and even a "degrowth" economy. ${ }^{6}$

Designers and design managers need to adopt a discriminating attitude toward the new technologies, just as much as they strike the same posture in relation to all other phe-

\footnotetext{
${ }^{6}$ Voted the best green think tank of 2011, the Center for the Advancement of the Steady State Economy (CASSE), in Arlington, Virginia, favors a steady-state economy. For its definition of steady state, the debt it owes E. F. Schumacher, and its concept of "degrowth," visit http://steadystate.org/.
}

nomena relevant to their professional practice. Yet they do also have a duty to explain and advocate far-reaching scientific research and open-ended technological experimentation. In the West, pressures to delay, take fright about, or underfund science and technology deserve resistance. Design managers need to know who their friends are, and should improve their knowledge of scientific and technological trends.

\section{Principle 5: See older people as quick} learners

Despite DT's emphasis on end users, the literature that surrounds it is weak on older people. Yet in Japan, Italy, Germany, and even China, design managers will meet an aging population in the years and decades to come. Meanwhile, in the United Kingdom, the number of years that 65-year-olds can expect to live without a disability is rising very rapidly (see Table 3 ).

How should designers make the best of these kinds of trends?

The real point to grasp is that older people today are not "just as young as they feel." It is too

\begin{tabular}{|l|l|l|l|}
\hline & $2000-2$ & $2004-6$ & $2006-8$ \\
\hline Males & 8.9 & 10.2 & 10.5 \\
\hline Females & 10.4 & 10.7 & 10.9 \\
\hline
\end{tabular}

Source: UK Office for National Statistics, 2010

Table 3. Years English 65-year-olds can expect to be free of disability, 2002-2008. trendy to think this, and too vague. This view neglects the very real physiological changes that set in once the human body turns 40 years old.

On the other hand, it is also too superficial to confine older people to a stereotype that sees their atrophied experiences from the past as the key to their specificity. It is nice that certain British retail chains employ old people because of their generation's familiarity with how to put up a shelf, or because of their experience of an earlier, more civil kind of customer service. Yet experience, as Oscar Wilde's novel The Picture of Dorian Grey suggests, is by itself of no ethical value; it is simply the name we give our mistakes. What counts are not just experiences of the past, but also the ability to learn from these, and from mistakes, so as to navigate the future adroitly.

Today's older people possess not just experiences, but also an inquiring outlook. Through their experience, older people can often find solutions for tomorrow's problems faster than young people. Design managers could start an excellent Next Trend in Design once they make a proper, neither starry-eyed nor patronizing, estimate of the talents of older customers. They should take seriously, too, the talents of older workers who use new designs in the workplace, and the talents of older designers as employees. 


\section{Conclusion}

This article has tried to give a hint of where trends come from. It has also given some guidance, if not about how the next intellectual trend will shape up, then certainly, in a spirit of activism, about what design managers ought to be encouraging as trends in design.

The Next Trend in Design should, we have argued, be back-tobasics, counter-inflationary, internationalist, pro-technology, and proolder people. This argument is based on today's realities, but seeks to go beyond them. Discontent, as Wilde remarked in his play $A$ Woman of No Importance, is the first step in the progress of a man or a nation. Equally, in the Maxims for Revolutionists in his play Man and Superman, George Bernard Shaw observed:

The reasonable man adapts bimself to the world; the unreasonable one persists in trying to adapt the world to bimself. Therefore all progress depends on the unreasonable man.

Tough though it may appear to be, the perspective set out here could form a simple, convincing, intelligent, and un-faddish new argument for the discipline of design itself. Here's why:

First, the perspective puts the accent on the visual and functional execution of design, in a way that anybody from senior manager to person in the street can recognize.
Second, it tries to make purchases cheaper, and sees a role for technology in helping that process along.

Third, while it can cheapen products and services, the Next Trend in Design refuses to cheapen the lives of people in emerging markets.

Fourth, the Next Trend seeks a powerful new alliance with scientists and technologists who want not to ameliorate disease, but eliminate it; who want top-class infrastructure for all, not Band Aid measures that work around the lack of infrastructure; who want the best, not second-best.

Last, the Next Trend in Design orientates to senior citizens as active powers, not as passive victims.

With this trend, the compass for design is neither stuck in stop-the-world environmentalism, nor spinning through any number of fanciful design futures. Naturally, the needle of this compass will change position, with changing times. But I believe that, right now, it points firmly in the direction of a better tomorrow-for design, for designers, and for the world.

Reprint \#11061WOU27

\section{References}

Ariely, D. (2009). "The End of Rational

Economics." Harvard Business

Review, July-August, pp. 73-84.
Bau, R. (2011). "The Value of Design-Deconstructed." Webinar recording, May 10.

Brown, T. (2009). Change by Design: How Design Thinking Transforms Organizations and Inspires Innovation. New York: HarperBusiness.

Byrne, J. (1986). "Business Fads: What's In-And Out." BusinessWeek, January 20, pp. 52-61.

Clinton, W. (1995a, March 29). "Message to the Congress on Science and Technology." From The American Presidency Project. Available at http://www.presidency. ucsb.edu/ws/index.php?pid=51167 \&st $=\& s t 1=\# a x z z 1 \mathrm{~g} 1 \mathrm{BuVbdI}$ (accessed December 9, 2011).

Clinton, W. (1995b, April 6). "Message to the Congress on Environmental Policy." From The American Presidency Project. Available at http://www.presidency. ucsb.edu/ws/index.php?pid=51197 \&st $=$ Message + to + the + Congress + on+Environmental+Policy\&st1=\# axzz1XTawkXGp (accessed December 9, 2011).

Cowen, T. (2011). The Great Stagnation: How America Ate All the Low-Hanging Fruit of Modern History, Got Sick, and Will (Eventually) Feel Better. New York: Dutton Books.

The Economist. (2010, August 5). "The New Frontier for Corporate Japan." Available at http://www. economist.com/node/16743435 (accessed December 9, 2011).

Ellsberg, D. (1961). "Risk, Ambiguity, and the Savage Axioms." Quarterly 
Journal of Economics, 75(4), pp. $643-669$.

Emerson, J. (2009, July 22). “100+ Years of Design Manifestos." Social Design blog. Available at http $\$ / /$ backspace.com/notes/2009/07/ design-manifestos.php (accessed December 9, 2011).

Freeman, R. (1984). Strategic Management: A Stakeholder Approach. Cambridge, UK: Cambridge University Press.

Freeman, R., Reed, D. (1983). "Stockholders and Stakeholders: A New Perspective on Corporate Governance." California Management Review, 25(3), pp. 88-106.

Hutton, W. (1995). The State We're In: Why Britain Is in Crisis and How to Overcome It. London: Vintage.

Immelt, J., et al. (2009). "How GE Is Disrupting Itself." Harvard Business Review, October, pp. 56-65.

Kahneman, D., Tversky, A. (1979). "Prospect Theory: An Analysis of Decision under Risk." Econometrica, 47(2), pp. 263-265.
Melly, G. (1970). Revolt into Style: Pop Arts in Britain. London: Allen Lane.

Nussbaum, B. (2011). “Design Thinking Is a Failed Experiment. So What's Next?" Co.Design, April 6.

Penn, M., Zalesne, E. (2007). Microtrends: The Small Forces Behind Tomorrow's Big Changes. New York: Twelve.

Sorrell, M. (2002). "Consumer is king as producers fight it out." The Times, February 20.

Zoellick, R. (2005). "Whither China: From Membership to Responsibility?" Remarks to the National Committee on U.S.-China Relations, September 21.

\section{Author biography}

James Woudhuysen is a professor of forecasting and innovation at De Montfort University, Leicester, UK. In 1968, before graduating from the University of Sussex with a degree in physics, he helped install Britain's first computer-controlled car park. He also spent time as editor of Design magazine and cofounded Blueprint magazine before becoming chief of worldwide market intelligence for Philips Consumer Electronics in the Netherlands and director of product designers for Seymour Powell. Now an independent consultant, he has written for many publications, including Applied Ergonomics, Computing, Cultural Trends, The Economist, The Institute of Mechanical Engineers Journal, Long Range Planning, New Civil Engineer, The Times, and The Guardian, and has written two books, Energise! A Future for Energy Innovation and Big Potatoes: The London Manifesto for Innovation. He is also a contributor to BBC Radio. His clients have included Amadeus, Brother, Geothermal Engineering, International Federation of Automotive Engineering Societies, Orange, O2, Mitsubishi, Navteq, Novartis, Roca, Sage, and SAP. 